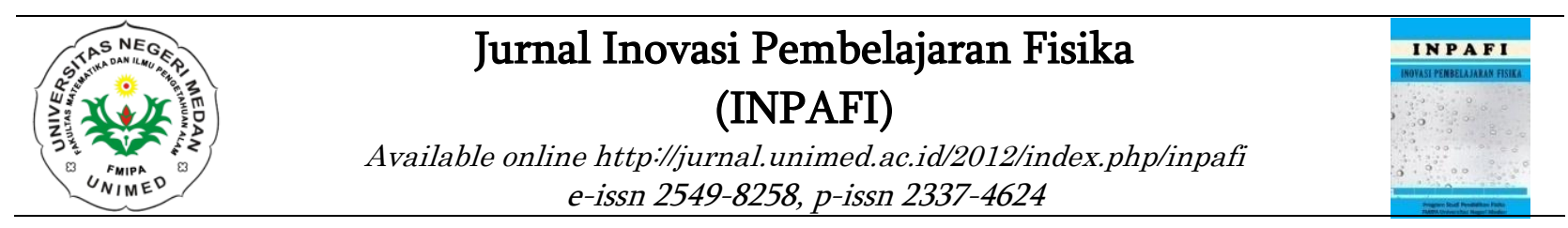

\title{
PENGARUH MODEL PEMBELAJARAN BERBASIS MASALAH TERHADAP HASIL BELAJAR SISWA PADA MATERI SUHU DAN KALOR DI KELAS X SEMESTER II SMA SWASTA NUSANTARA LUBUK PAKAM T.P. 2016/2017
}

\author{
Siska Boangmanalu dan Sondang R. Manurung \\ Jurusan Fisika FMIPA Universitas Negeri Medan \\ siskaboangmanalu29@gmail.com, sondangrina@gmail.com
}

Diterima: September 2018. Disetujui: Oktober 2018. Dipublikasikan: Nopember 2018

\begin{abstract}
ABSTRAK
Penelitian ini bertujuan untuk mengetahui pengaruh model pembelajaran berbasis masalah terhadap hasil belajar siswa pada materi suhu dan kalor di kelas X semester II SMA Swasta Nusantara Lubuk Pakam T.P 2016/2017. Jenis penelitian ini adalah quasi experiment dengan menggunakan two group pretest-posttest design. Populasi dalam penelitian adalah seluruh siswa kelas X semester II SMA Swasta Nusantara Lubuk Pakam T.P 2016/2017. Pengambilan sampel dilakukan dengan cara random sampling dengan mengambil 2 kelas yaitu kelas X MIA 1 dengan jumlah siswa 32 orang dan kelas X MIA 2 dengan jumlah siswa 34 orang. Instrumen yang digunakan dalam penelitian ini yaitu : tes hasil belajar, dan lembaran observasi aktivitas siswa. Instrumen yang digunakan untuk mengetahui hasil belajar siswa adalah tes hasil belajar yang berbentuk essay tes dengan jumlah 10 soal. Hasil penelitian diperoleh nilai rata-rata pretest kelas eksperimen 39,40 dan nilai rata-rata kelas kontrol 38,08. Setelah diberikan perlakuan, nilai ratarata posttest kelas eksperimen menjadi 76,17 dan kelas kontrol 61,69. Berdasarkan hasil uji hipotesis menggunakan uji t maka dapat disimpulkan bahwa ada pengaruh yang signifikan terhadap hasil belajar fisika siswa dengan model pembelajaran berbasis masalah pada materi Suhu dan Kalor di kelas X Semester II SMA Swasta Nusantara Lubuk Pakam T.P 2016/2017.
\end{abstract}

Kata kunci : model pembelajaran berbasis masalah, pembelajaran konvensional, hasil belajar.

\section{ABSTRACT}

This research aimed is to know the effect of problem based learning models to improve learning outcomes physics in temperature and heat in class X second semester SMA Private Nusantara of Lubuk Pakam Academic Year 2016/2017. This research is a quasi experiment study with control group pretest-posttest design. The population in this research is the whole student in class X SMA Private Nusantara of Lubuk Pakam Academic Year 2016/2017. Technique sampling istaken for 2 classes are determined by random sampling, is class X MIA 1 with total 32 students and X MIA 2 with total 32 students. The instruments used in this research are: learning result test, and student activity observation sheet. The instrument used to determine student learning outcomes is a test of learning outcome that is essay test there are 10 questions. The research result, it is got the average value of experiment class pretest 39,40 and the average value of control class 38,08. After the experimental class treatment, the mean grade of the experimental class was 76.17 and the control class 61.69 . The 
Siska Boangmanalu dan Sondang R. Manurung : Pengaruh Model Pembelajaran Berbasis Masalah Terhadap Hasil Belajar Siswa Pada Materi Suhu Dan Kalor Di Kelas X Semester II

SMA Swasta Nusantara Lubuk Pakam T.P. 2016/2017

hypothesis test using different test ( $\mathrm{t}$-test) obtained that is significant effect from using problem based learning model outcomes of student in subject temperature and heat in class X second semester SMA Private Nusantara of Lubuk Pakam Academic Year 2016/2017.

\section{Keywords : problem based learning, conventional learning, learning outcomes.}

\section{PENDAHULUAN}

Sains adalah suatu kumpulan pengetahuan tersusun secara sistematik, dan dalam penggunaanya secara umum terbatas pada gejala-gelaja alam. Perkembanganya tidak hanya ditandai oleh adanya kumpulan fakta, tetapi oleh adanya metode ilmiah dan sikap ilmiah. American Association for the Advancement of Science (AAAS 1993), menekankan sains sebagai produk, proses, dan sikap.

Proses pembelajaran sains khususnya fisika juga mestinya menekankan pada pemberianpengalaman langsung kepada siswa, sehingga siswa memperoleh pemahaman mendalam tentang alam sekitardan prospek pengembangan lebih lanjut dapat menerapkannya di dalam kehidupan seharihari. Pembelajaran fisika di sekolah seharusnya melibatkan aspek sikap, proses, dan produk, sehingga siswa dapat mengalami proses pembelajaran secara utuh, memahami fenomena alam melalui kegiatan pemecahan masalah, metode ilmiah, dan meniru kerja ilmuan dalam menemukan fakta baru. Kecenderungan pembelajaran fisika saat ini, siswa hanya mempelajari fisika sebagai produk, menghapalkan konsep, teori dan hukum, serta berorientasi pada hafalan. Akibatnya, sikap, proses, dan aplikasi tidak tersentuh dalam pembelajaran. Pengalaman belajar yang diperoleh di kelas tidak utuh dan tidak berorientasi tercapainya standar kompetensi dan kompetensi dasar. Sistem pembelajaran ini suasana kelas cenderung teacher-centered, guru hanya menyampaikan fisika sebagai produk dan siswa menghapal informasi faktual.

Hal ini terbukti berdasarkan pengalaman peneliti saat melakukan Praktek Program Pengalaman Lapangan Terpadu, banyak siswa yang mengatakan bahwa pelajaran fisika itu merupakan pelajaran yang sulit untuk dipahami dan pelajaran yang membosankan. Guru lebih sering menggunakan pola mengajar dengan menyajikan materi dan penyelesaian soal-soal dengan rumus, sehingga siswa hanya dapat menghitung tetapi tidak dapat mengerti konsep fisika sebenarnya. Permasalahan lain yang dijumpai di sekolah tersebut adalah kurangnya keterampilan siswa di dalam penggunaan alat-alat laboratorium. Siswa masih banyak yang belum bisa menggunakan peralatan-peralatan yang ada di dalam laboratorium dan bahkan masih banyak siswa yang belum mengenal alat-alat dan bahan apa saja yang ada di dalam laboratorium dikarenakan saat pembelajaran sangat jarang sekali menggunakan metode eksperimen/ percobaan di laboratorium.

Hasil dan bukti belajar adalah terjadinya perubahan tingkah laku pada orang tersebut. Misalnya dari tidak tahu menjadi tahu, dan dari tidak mengerti menjadi mengerti (Hamalik, 2010:30). Rendahnya hasil belajar fisika yang diperoleh siswa disebabkan kurang efektifnya pembelajaran yang digunakan oleh guru dan penggunaan model pembelajaran yang tidak bervariasi sehingga menimbulkan kejenuhan pada diri siswa. Karena pada saat pembelajaran berlangsung guru lebih sering menggunakan metode ceramah, mencatat, mengerjakan soal dan kadang-kadang membuat metode demonstrasi walaupun hanya pada materi tertentu saja namun jarang menghubungkan pembelajaran tersebut dengan contoh-contoh dalam aplikasi kehidupan sehari-hari. Selain itu juga disebabkan berbagai hal termasuk faktor yang terdapat dalam diri siswa tersebut seperti sikap mereka terhadap pelajaran fisika , dimana mereka beranggapan bahwa pelajaran fisika adalah pelajaran yang paling susah dimengerti karena di samping mengetahui teori juga 
menghapal banyak rumus sehingga siswa lebih dahulu, merasa jenuh sebelum mempelajarinya.

Salah satu alternatif yang dapat digunakan untuk mengatasi kesulitan tersebut adalah dengan menciptakan suasana pembelajaran yang langsung berhubungan dengan kehidupan sehari-hari. Salah satu model pembelajaran yang dapat dilakukan untuk memperbaiki proses pembelajaran di sekolah tersebut adalah dengan menerapkan model pembelajaran berdasarkan masalah. Model pebelajaran ini dirancang dengan tujuan untuk membentu siswa mengembangkan kemampuan berpikir dan mengembangkan kemampuan dalam memecahkan masalah kehidupan seharihari dengan cara menggali infomasi sebanyakbanyaknya kemudian menganalisis dan mecari solusi dari permasalahan yang ada. Menurut Arends (2012), model problem based learning adalah suatu pendekatan pembelajaran dimana siswa mengerjakan permasalahan yang autentik dengan maksud untuk menyusun pengetahuan mereka sendiri, mengembangkan inkuiri dan keterampilan berpikir tingkat tinggi, mengembangkan kemandirian dan percaya diri.

Penerapan model pembelajaran berbasis masalah juga sudah pernah digunakan oleh para peneliti. Hasil penelitian yang dilakukan oleh Destianingsih et al, (2014), menunjukkan bahwa aktivitas siswa juga dapat menjadi data pendukung untuk memperkuat hasil penelitian ini. Melalui observasi aktivitas siswa, peneliti dapat mengetahui seberapa aktif dan antusiasnya siswa dalam pembelajaran karena siswa yang memiliki peranan yang aktif dan antusias dalam pembelajaran akan memiliki kemampuan belajar yang lebih mandiri sehingga melalui model problem based learning ini, aktivitas siswa selama proses pembelajaran berlangsung selalu mengalami peningkatan dari tiap pertemuannya.

Penelitian tentang penggunaan model pembelajaran berbasis masalah juga dilakukan oleh Novriyanti dan Derlina (2014). Hasil penelitian diperoleh bahwa hasil belajar siswa pada materi pokok suhu dan kalor dengan menggunakan model pembelajaran berbasis masalah secara individu terdapat 18 orang siswa yang tuntas $(60 \%)$ dan secara kelas dinyatakan tidak tuntas (jumlah siswa yang tuntas tidak mencapai 85\%). Hasil belajar siswa pada materi pokok suhu dan kalor dengan menggunakan pembelajaran konvensional secara individu terdapat 13 orang siswa yang tuntas $(42 \%)$ dan secara kelas dinyatakan tidak tuntas (jumlah siswa yang tuntas tidak mencapai 85\%). Aktivitas belajar siswa pada materi pokok suhu dan kalor dengan menggunakan model pembelajaran berbasis masalah di kelas X SMA Negeri 1 Delitua Semester Genap T.P. 2013/2014 termasuk kategori cukup aktif. Besarnya peningkatan hasil belajar fisika siswa dalam penelitian ini diperoleh karena adanya beberapa kebaikan dari model pembelajaran berbasis masalah dibandingkan pembelajaran konvensional, dimana model pembelajaran berbasis masalah lebih berpusat pada siswa sehingga dapat mengembangkan kemampuan siswa dalam kehidupan nyata untuk menemukan pengetahuan baru, realistik dengan kehidupan siswa (Trianto, 2009:96).

\section{METODE PENELITIAN}

Penelitian ini dilaksanakan di SMA Swasta Nusantara Lubuk Pakam, beralamat di jalan Teuku Raja Muda nomor 01 Lubuk Pakam dengan waktu pelaksanaanya pada tahun pelajaran 2016/2017 semester II. Populasi penelitian ini adalah siswa kelas X SMA Swasta Nusantara Lubuk Pakam Tahun Pelajaran 2016/2017. Pengambilan sampel menggunakan teknik random sampling. Satu kelas dijadikan sebagai kelas ekperimen yang diajar dengan model pembelajaran berbasis masalah dan satu kelas lagi dijadikan sebagai kelas kontrol yang diajar dengan pembelajaran konvensional.

Jenis penelitian ini adalah quasi experiment (eksperimen semu) yaitu penelitian yang dimaksudkan untuk mengetahui ada tidaknya akibat dari sesuatu yang dikenakan pada subjek yaitu siswa. Penelitian ini dimaksudkan untuk mengetahui ada atau tidaknya pengaruh model pembelajaran problem based learning terhadap hasil belajar siswa. Kelas eksperimen diberi model pembelajaran berbasis masalah sedangkan kelas kontrol diberi model pembelajaran konvensional.

Kedua kelas tersebut digolongkan menjadi dua kelompok dimana kelompok eksperimen dikenal variabel perlakuan $\mathrm{X}$ dan kelompok kontrol 
Siska Boangmanalu dan Sondang R. Manurung : Pengaruh Model Pembelajaran Berbasis Masalah Terhadap Hasil Belajar Siswa Pada Materi Suhu Dan Kalor Di Kelas X Semester II

SMA Swasta Nusantara Lubuk Pakam T.P. 2016/2017

tanpa diberi perlakuan Y. Desain penelitian tipe two group ( pretest dan posttest ). dapat digambarkan sebagai berikut.

Tabel 1. Desain Penelitian tipe two group (pretest dan posttest).

\begin{tabular}{|c|l|c|c|c|}
\hline No & Sampel & Pretes & Perlakuan & Postes \\
\hline 1. & Eksperimen & $\mathrm{T}_{1}$ & $\mathrm{X}$ & $\mathrm{T}_{2}$ \\
\hline 2. & Kontrol & $\mathrm{T}_{1}$ & $\mathrm{Y}$ & $\mathrm{T}_{2}$ \\
\hline
\end{tabular}

Keterangan:

$\mathrm{X}=$ Pengajaran dengan menggunakan model pembelajaran problem based learning

$\mathrm{Y}=$ Pengajaran dengan menggunakan model pembelajaran konvensional

$\mathrm{T}_{1}=$ Tes kemamapuan awal (Pretest) untuk kelas eksperimen dan kelas control

$\mathrm{T}_{2}=$ Tes kemamapuan akhir (Posttest) untuk kelas eksperimen dan kelas control

Analisis data bertujuan untuk menguji apakah hipoesis yang dikemukakan dalam penelitian diterima atau ditolak. Analisis dilakukan untuk melihat perbedaan rata-rata kedua kelas sampel berarti atau tidak. Ananlisis data menggunakan uji hipotesis yaitu uji kesamaan rata-rata posttest (Sudjana, 2005).

\section{HASIL DAN PEMBAHASAN}

\section{a. Hasil Penelitian}

Tahap awal penelitian, kedua kelas diberikan tes uji kemampuan awal (pretest) yang bertujuan untuk mengetahui kemampuan awal siswa pada kedua kelas sama atau tidak.

Berdasarkan data yang diperoleh, nilai rata-rata pretest siswa di kelas eksperimen adalah 39,40 dengan nilai tertinggi 65 dan nilai terendahnya 10 . Nilai rata-rata pretest siswa di kelas kontrol adalah 38,08 dengan nilai tertinggi 65 dan nilai terendahnya 10. Perolehan hasil nilai pretest pada kedua kelas ditunjukkan pada tabel 2 dan tabel 3.

Tabel 2. Data nilai pretest pada kelas eksperimen

\begin{tabular}{|c|c|c|c|}
\hline \multicolumn{4}{|c|}{ Kelas Eksperimen } \\
\hline Nilai & Frekuensi & $\begin{array}{c}\text { Rata- } \\
\text { rata }\end{array}$ & $\begin{array}{l}\text { Standar } \\
\text { Deviasi }\end{array}$ \\
\hline $10-18$ & 1 & \multirow{7}{*}{39,40} & \multirow{7}{*}{11,19} \\
\hline $19-27$ & 2 & & \\
\hline $28-36$ & 11 & & \\
\hline $37-45$ & 9 & & \\
\hline $46-54$ & 6 & & \\
\hline $55-63$ & 2 & & \\
\hline $64-72$ & 1 & & \\
\hline$\sum$ & $=32$ & & \\
\hline
\end{tabular}

Tabel 3. Data nilai pretest pada kelas kontrol

\begin{tabular}{|c|c|c|c|}
\hline \multicolumn{4}{|c|}{ Kelas Kontrol } \\
\hline Nilai & Frekuensi & $\begin{array}{l}\text { Rata- } \\
\text { rata }\end{array}$ & $\begin{array}{l}\text { Standar } \\
\text { Deviasi }\end{array}$ \\
\hline $10-18$ & 3 & \multirow{7}{*}{38,08} & \multirow{7}{*}{14,20} \\
\hline $19-27$ & 5 & & \\
\hline $28-36$ & 7 & & \\
\hline $37-45$ & 11 & & \\
\hline $46-54$ & 2 & & \\
\hline $55-63$ & 4 & & \\
\hline $64-72$ & 2 & & \\
\hline \multicolumn{2}{|c|}{$\sum=34$} & & \\
\hline
\end{tabular}

Data pretest memenuhi persyaratan normalitas dan homogenitas sehingga penelitian ini menggunakan uji kesamaan pretest (uji $\mathrm{t}$ dua pihak). Perhitungan uji kesamaan nilai rata-rata pretest kedua sampel yaitu thitung $<t_{\text {tabel }}$ atau $0,42<1,998$ sehingga dapat disimpulkan bahwa kemampuan awal siswa kelas eksperimen dan kelas kontrol adalah sama.

Setelah kedua kelas diberikan perlakuan yang berbeda, dimana kelas eksperimen menggunakan model pembelajaran berbasis masalah sedangkan kelas kontrol dengan menggunakan model pembelajaran konvesional. Hasil yang diperoleh untuk kelas eksperimen dan kelas kontrol setelah diberi perlakuan dapat dilihat pada Tabel 4.

Tabel 4. Data nilai posttest pada kelas eksperimen. 


\begin{tabular}{|c|c|c|c|}
\hline \multicolumn{4}{|c|}{ Kelas Eksperimen } \\
\hline Nilai & Frekuensi & $\begin{array}{l}\text { Rata- } \\
\text { rata }\end{array}$ & $\begin{array}{l}\text { Standar } \\
\text { Deviasi }\end{array}$ \\
\hline $50-57$ & 2 & \multirow{6}{*}{76,17} & \multirow{6}{*}{12,58} \\
\hline $58-65$ & 8 & & \\
\hline 66-73 & 0 & & \\
\hline 74-81 & 10 & & \\
\hline $82-89$ & 4 & & \\
\hline $90-97$ & 8 & & \\
\hline & & & \\
\hline
\end{tabular}

Tabel 5. Data nilai posttest pada kelas kontrol

\begin{tabular}{|c|c|c|c|}
\hline \multicolumn{4}{|c|}{ Kelas Kontrol } \\
\hline Nilai & Frekuensi & $\begin{array}{c}\text { Rata- } \\
\text { rata }\end{array}$ & $\begin{array}{c}\text { Standar } \\
\text { Deviasi }\end{array}$ \\
\hline $30-38$ & 1 & & \\
\hline $39-47$ & 2 & & \\
\cline { 1 - 2 } $48-56$ & 4 & \multirow{2}{*}{61,69} & \multirow{2}{*}{11,12} \\
\cline { 1 - 2 } $57-65$ & 15 & & \\
\cline { 1 - 2 } $66-74$ & 8 & & \\
\cline { 1 - 2 } $75-83$ & 3 & & \\
\hline $84-92$ & 7 & & \\
\hline \multicolumn{2}{|c|}{$3=34$} & & \\
\hline
\end{tabular}

Hasil posttest yang diperoleh untuk kelas eksperimen setelah diberi perlakuan adalah 76,17. Nilai terendah pada kelas eksperimen adalah 50 dan nilai tertingginya 95 . Sementara itu, nilai rata-rata kelas kontrol pada postest sebesar 61,69 dengan nilai terendahnya 30 dan nilai tertinggi 85 .

Pembelajaran berbasis masalah selain untuk meningkatkan hasil belajar siswa dapat juga meningkatkan aktivitas belajar siswa, hal ini ditunjukkan dari hasil observasi aktivitas belajar siswa yang dilakukan dengan dua observer yaitu rekan peneliti. Observasi yang dilakukan selama kegiatan proses belajar mengajar yang terdiri dari 4 kali pertemuan. Hasil peningkatan aktivitas belajar siswa ditunjukkan pada tabel 6 .

Tabel 6. Rata-rata aktivitas belajar siswa pada kelas eksperimen

\begin{tabular}{|c|c|c|c|}
\hline & $\begin{array}{c}\text { Pertemuan } \\
\text { ke }\end{array}$ & $\begin{array}{c}\text { Rata-rata } \\
\text { aktivitas siswa }\end{array}$ & Kriteria \\
\hline 1. & I & 64,13 & kurang aktif \\
\hline 2. & II & 66,21 & cukup aktif \\
\hline 3. & III & 73,12 & cukup aktif \\
\hline 4. & IV & 78,65 & aktif \\
\hline \multicolumn{2}{|c|}{ Rata-rata } & 70,52 & cukup aktif \\
\hline
\end{tabular}

Tabel 6 menunjukkan nilai rata-rata aktivitas belajar siswa pada kelas eksperimen. Aktivitas belajar siswa di kelas eksperimen yang menggunakan model pembelajaran berbasis masalah selalu mengalami peningkatan pada setiap pertemuan. Pertemuan I menunjukkan aktivitas siswa yang kurang aktif dengan nilai rata-rata 64,41. Pertemuan II menunjukkan aktivitas siswa yang mengalami peningkatan dengan nilai rata-rata 66,63, dengan kategori cukup aktif. Pertemuan III rata-rata nilai aktivitas siswa adalah sebesar 73,74 dengan kategori yang masih sama dengan pada peretemuan II yaitu cukup aktif hanya saja nilai rata-ratanya mengalami peningkatan. Sementara itu pada pertemuan IV, menunjukkan aktivitas siswa dari kategori cukup aktif menjadi aktif dengan rata-rata nilai 78,72. Hal ini menunjukkan bahwa siswa semakin aktif dalam proses belajar mengajar. Nilai rata-rata aktivitas siswa seluruhnya adalah 70,52 dengan kriteria penilaian cukup aktif.

\section{b. Pembahasan Hasil Penelitian}

Hasil penelitian menunjukkan bahwa ada pengaruh yang signifikan terhadap hasil belajar siswa dengan menggunakan model pembelajaran berbasis masalah pada materi pokok suhu dan kalor di SMA Swasta Nusantara Lubuk Pakam T.P 2016/2017.

Besarnya peningkatan hasil belajar fisika siswa dalam penelitian ini diperoleh karena adanya beberapa kebaikan dari model pembelajaran berbasis masalah dibandingkan pembelajaran konvensional, dimana model pembelajaran berbasis masalah lebih berpusat pada siswa sehingga dapat menantang kemampuan siswa untuk menemukan pengetahuan baru, dapat meningkatkan aktivitas pembelajaran siswa, dan dapat membantu siswa bagaimana mentransfer pengetahuan mereka 
Siska Boangmanalu dan Sondang R. Manurung : Pengaruh Model Pembelajaran Berbasis Masalah Terhadap Hasil Belajar Siswa Pada Materi Suhu Dan Kalor Di Kelas X Semester II

SMA Swasta Nusantara Lubuk Pakam T.P. 2016/2017

untuk memahami masalah-masalah fisika dalam kehidupan nyata seperti pertanyaan di lembar LKS yang telah dirancang oleh peneliti pada saat akan diadakan diskusi antar kelompok.

Hasil penelitian ini juga sesuai dengan penelitian terdahulu oleh Situmorang dan Manurung (2016) dengan kesimpulan ada pengaruh lebih pada model pembelajaran berbasis masalah dengan bantuan animasi macromedia flash terhadap hasil belajar dan aktivitas siswa pada materi pokok suhu dan kalor di selas X semester II SMA Katolik Trisakti Medan T.P. 2015/2016. Selain itu penelitian tentang penerapan model pembelajaran berbasis masalah juga dilakukan oleh Shiddiqy dan Manurung (2016). Hasil penelitian disimpulkan bahwa aktivitas belajar di kelas eksperimen mengalami peningkatan yang signifikan daripada kelas kontrol. Dan berdasarkan hasil uji hipotesis menggunakan uji beda (uji t), diperoleh hasil belajar dengan peneapan model pembelajaran berbasis masalah menggunakan media animasi memiliki peningkatan yang signifikan daripada hasil belajar dengan penerapan model konvensional.

Pembelajaran berbasis masalah selain untuk meningkatkan hasil belajar siswa dapat juga meningkatkan aktivitas belajar siswa, hal ini ditunjukkan dari hasil observasi aktivitas belajar siswa, mulai pertemuan I sampai pertemuan IV pada kelas eksperimen. Aktivitas belajar pada setiap pertemuan pada kelas eksperimen selalu mengalami peningkatan.

Dari data hasil penelitian pada kelas eksperimen tersebut, ada beberapa siswa yang nilai aktivitasnya meningkat tetapi hasil belajarnya rendah. Siswa yang nilai aktivitasnya cukup aktif tetapi nilai postest nya kurang, hal ini berarti kemampuan kognitif siswa itu rendah, sedangkan kemampuan psikomatornya tinggi. Berdasarkan pengamatan dari peneliti siswa tersebut hanya serius mengikuti pembelajaran pada saat melakukan eksperimen akan tetapi pada saat peneliti menjelaskan teori siswa hanya terfokus pada hasil eksperimen. Siswa tersebut terlalu cepat merasa puas hanya pada hasil eksperimen, sehingga pada saat diberikan soal postest yang mirip ataupun tidak sama dengan yang ada pada LKS maka siswa mengalami kesulitan dalam menyelesaikan soal. Selain dapat meningkatkan hasil belajar dan aktivitas siswa, tetapi dalam pelaksanaan pada saat penelitian, peneliti masih mengalami beberapa kendala yang dihadapi. Hal itu disebabkan karena kelemahan model pembelajaran berbasis masalah diantaranya :1) Peneliti belum berpengalaman mengajar menggunakan model pembelajaran berbasis masalah sehingga semua sintaks kurang efektif saat pelaksanaan proses pembelajaran, 2) peneliti masih sulit menentukan masalah apa yang sesuai untuk diselesaikan saat proses pembelajaran berlangsung karena masalah yang diberikan haruslah sesuai dengan apa yang pernah siswa alami dalam kehidupan seharihari, 4) Sering terjadi miss konsepsi 5) Konsumsi waktu yang banyak, dimana model ini memerlukanwaktu yang cukup lama dalam proses penyelidikan, sehingga terkadang banyak waktu yang tersita untuk proses tersebut dan 6) Pada saat menyajikan hasil diskusi, sebagian siswa kurang antusias untuk mempresentasikan hasil diskusinya dan memilih diam sehingga kegiatan kelompok selalu didominasi oleh siswa yang sama pada setiap pertemuan.

\section{KESIMPULAN DAN SARAN}

\section{a. Kesimpulan}

Berdasarkan hasil penelitian yang dilakukan menggunakan model pembelajaran berbasis masalah terhadap hasil belajar siswa pada materi suhu dan kalor, dapat disimpulkan bahwa ada pengaruh yang signifikan terhadap hasil belajar siswa dengan menggunakan model pembelajaran berbasis masalah pada materi pokok suhu dan kalor di SMA Swasta Nusantara Lubuk Pakam T.P 2016/2017

\section{a. Saran}

Berdasarkan pembahasan hasil penelitian disarankan beberapa hal sebagai berikut :

1. Bagi peneliti selanjutnya yang ingin melakukan penelitian dengan menggunakan model pembelajaran berbasis masalah, sebaiknya menguasai 
terlebih dahulu setiap sintaks yang terdapat dalam model, supaya kegiatan pembelajaran dapat berlangsung dengan baik.

3. Bagi peneliti selanjutnya hendaknya lebih memahami bagaimana mengambil masalah yang autentik, yaitu masalah nyata yang sering terjadi dalam kehidupan sehari-hari dalam pembelajaran berbasis masalah untuk dipecahkan oleh siswa yang akan diberi perlakuan.

4. Bagi peneliti selanjutnya yang ingin meneliti model pembelajaran berbasis masalah lebih lanjut, disarankan untuk memperhatikan efisiensi waktu sehingga semua sintaks efektif saat pelaksanaan proses pembelajaran.

\section{DAFTAR PUSTAKA}

American Association for the Advancement of Science. (1993). Benchmarks for Science Literacy : A Project 2016 report. New York : Oxford University Press

Arends, R. (2012). Belajar untuk Mengajar. Jakarta : Salemba Humanika.

Destianingsih, E., Pasaribu, A., dan Ismet. (2014). Pengaruh Model Problem Based Learning Terhadap Kemampuan Pemecahan Masalah Siswa Pada Pembelajaran Fisika Kelas XI di SMA Negeri 1 Tanjung Lubuk. Jurnal Inovasi Dan Pembelajaran; 1-6

Hamalik, O. (2010). Proses Belajar Mengajar. Jakarta : Bumi aksara

Novriyanti, A dan Derlina. (2014). Pengaruh Model Pembelajaran Berbasis Masalah Terhadap Hasil Belajar Siswa Pada Materi Pokok Suhu dan Kalor di Kelas X Semester II SMA Negeri 1 Delitua. Jurnal Inpafi. 2(4); 89-96

Shiddiqy, A.R.A dan Manurung, S.R. (2016) . Pengaruh Model Pembelajaran Berbasis Masalah Berbantuan Animasi Terhadap Hasil Belajar Siswa Pada Materi Fluida
Dinamis Di Kelas XI Semester II SMA Negeri 1 Lubuk Pakam Tahun Ajaran 2015/2016. Jurnal Ikatan Alumni Fisika Universitas Negeri Medan. 2(2); 14-18

Situmorang, J. A dan Manurung, S.R. (2016). Pengaruh Model Pembelajaran Berbasis Masalah Dengan Bantuan Animasi Terhadap Hasil Belajar Siswa. Jurnal Ikatan Alumni Fisika Universitas Negeri Medan. 2(4); 91-95

Sudjana. (2005). Metode Statistika .Bandung: Tarsito

Sukarman, M.A., Ali, M., dan Pasaribu, M. (2012). Pengaruh Model Pembelajaran Berbasis Masalah Terhadap Hasil Belajar Fisika Pada Siswa Kelas XI SMA Negeri 5 Palu.Jurnal Pendidikan Fisika Tadulako (JPFT). 1(2); 39-43

Trianto. (2009). Mendesain Model Pembelajaran Inovatif-Progresif. Jakarta: Kencana 